\title{
The Defensive Strength of Russia
}

\section{Major Maurice Rech}

To cite this article: Major Maurice Rech (1892) The Defensive Strength of Russia, Royal United Services Institution. Journal, 36:171, 582-593, DOI: 10.1080/03071849209417651

To link to this article: http://dx.doi.org/10.1080/03071849209417651

\section{曲 Published online: 11 Sep 2009.}

Submit your article to this journal $\pi$

Џll Article views: 2

Q View related articles $\longleftarrow$ 


\section{THE DEFENSIVF STRENGTH OF RUSSIA."}

Compiled by M[ajor MLunice Recr, Imperial and Royal AustroHungarian Arms. 'Translated by Major C. E. DE Ld POEl: Brresrond, Wilts Regiment.

General Ofjicers on Service at St. Petersbuigh.

War Mlinister: General (of infantry) Wannorski. Adlatus and Private Secretary : General (of infantry) Durnoro. Chicf of the General Staff: Genernl (of infantry) Obrutsheff. Adlatus: Jieutenant-General Welitschko.

Inspector-General of the Artillery: H.I.H. Grond Duke Michael (Ficld Marshal).

Inspector-General of the Cossacks (Ataman): H.I.H. Grand Duke Nicholas Alexandrovitch (Czarewitch).

Director of T'echnical Milministration: Mrajor-Geneml Saboltkin.

Inspector-Genernl of Rifle Battalions: Genernl (of infantry) ron Nothbeck.

Inspector-General of Caralrg: H.I.H. Grand Dake Miehael (Field Marshal).

Governors-General of the most important Goternments.

Warsuu : General (of cnvalry) ron Gourko, also Commander-inChicf of the Troops, and, in case of war, Presumptive Chicf of the Forces in Russian Poland.

Iroscow : H.I.H. Maror-General Grand Duke Sergins.

Fielÿ: General (of infantry) Ignatieff.

Caucasus: Gencral (of cavalry) Scheremeticff, also Commander-in. Chicf of the 'Troops.

\section{Military District Commanders (the most important).}

St. Petersturgh: II.I.II. Lieutenant-General Grand Duke Vladimir.

Warsaw: Gencral (of cavaliy) von Gourko.

Wilna: Gereral (of infantry) Panetski II.

Kieff: General (of infantry) von Dragomiroff.

Yoscuw: Gencral (of artillerg) Kostanda.

1 From the " Jfilitär Zeitung," Februarg 21, 1S92. 
Army Corps Commanders.

Guard Corps ........ St. Petersbargh : Gen. (car.) von Manse.

Grenadier Corps .... Moscow : Lieut.-Gen. Malachòff.

1st Army Corps .... St. Petersburgh : Lieut.-Gen. Danilòff.

and " " .... Wilna: Gen. (cav.) Baron Dricsen.

3rd " $" \quad \ldots$. Riga: Gen. (inf.) Alchasòff.

4th " $" \quad \ldots$. Mlinsk: Gen. (inf.) Petruscherski.

5th " " $"$.... Warsaw: Gen. (art.) Sviestunòlf.

6lh " $"$ "... Warsaw: Gen. (inf.) Kulgatschèff.

7th $" \quad " \quad \ldots$. Scrastopol : Licut.-Gen. Janòrski,

8th " " $"$.... Odessa : Gen. (of cugineers) Röhrberg.

9th " $" \quad \ldots$. Kieff: Ijient.-Gen. Òrander.

10th " $" \quad \ldots$. Charkoff : Licnt.Gen. Winberg.

11th " " .... Zitomir: Lieut.-Gen. Prince Schachòvstoje.

12th $" \quad " \quad \ldots$ Uman : Lieut.-Gen. Srerjeff.

13th " $" \quad \ldots$. Moscow : Lieut.-Gen. Igelströn.

14th " $"$.... Lublin : Lieut.-Gen. Krschivòblotski.

15th " " .... Warsaw: Licut.-Gon. Mirkoritsch.

IGth " " .... Vitebsk: Lieut.-Gen. Richter.

17th " " .... N. Norgorod : Lient.-Gen. Saljesoff.

Caucasus Army Corps - Tiflis : Lient.-Gen. Count 'I'schavtschavadse. Finland ......... $\left\{\begin{array}{l}\text { Commander-in-Chief, Gen. (inf.) Count } \\ \text { Ieyden. }\end{array}\right.$ Chicf of the Staff, Maj.-Gen.:Kaulbars.

\section{Inspectors-General of F'ortresses.}

Group I: Lieutenant-General $\Lambda$ nossoff; including the fortresses Bobruisk, Brest-Iitorski, Dünaburg, Dïnamünde, Gonionds, Irangorod, Kars, Kertsch, and Petshersk in Kieff.

Group II : Lieutenant:General Parloff; including the fortresses Korno, Kronstadt, Mlichaelòro, Noro-Georgiersk, Odessa, Ossowez, Otschakor, Poti, St. Petersburgh (St. Peter and St. Paul Fort), Scrastopol, Sreaborg, Wyb rg.

Group III : Major-Gencral Stepanoff. The fortified places Ackalzich, Alesandropol, Ardahan, Batoum, Bender.

\section{Distrinutios of Troops.}

Ist Mrilitary District, St. Petersburgh.

Commander, H.I.II. Grand Duke Vladimir, \&c.

Guard Corps, consisting of -

lst Guard Cavalry Division (2 Guard Don Cossack regiments, 1 Ural Cossack sotnia, 4 Guard Cuirassier regiments), together 25 squadrons, of which 9 now in Warsar.

2nd Guard Caralry Division (7 regiments in 3 brigades), 42 squadrons. 
Guard Riflo Brigade.

lst and 2nd Guard Infantry Divisions.

1st aud 2nd Guard Artillery Brigndes.

All the abore, with the exception of 9 squadrons in Warsaw, in St. Petersburgh.

Ist Army Corps, St. Petersburgh District :-

1 cavalry division at 'Twer. 4 sotnias of Kuban and Terek Cossacks, of which 2 sotnias at Gatschina as escort to the Emperor.

37th Infantry Division and the Guard Horse Artillery Brigade (St. Petersburgh). 22nd Infantry Division, 22nd and 37th Artillery Brigades and Ist Reserve Artillery Brigade (Novgorod). 23rd In. fantry Division and 23rd Artillory Brigade at leval and Gatschina. lst Sapper (Engineer) Brigade, and 11 infantry reserve battalions, St. Petersburgh: together numbering

$$
\begin{aligned}
& 95 \text { battalions, } \\
& 62 \text { squadrons, } \\
& 6 \text { horse artillery batteries, } \\
& 36 \text { ficld artillery batteries. }
\end{aligned}
$$

IInd Military District, Finland.

Commander, General Adjutant and Infantry General Count Heyden, dic.

19th Don Cossack Regiment, Abo.

24th Infautry Division

$\left.\begin{array}{l}\text { 24th Artillery Brigade } \\ 4 \text { cudre infantry battalions }\end{array}\right\}$ Irelsingfors.

9 rifle battalions : together numberine

$$
\begin{aligned}
& 29 \text { battalions, } \\
& 6 \text { squadrons, } \\
& 6 \text { batteries. }
\end{aligned}
$$

\section{IIIrd Military District, Wílna.}

Conmander, Gencral (of infantry) ron Ganetzki.

2nd Army Corps, Wilna : consisting of the 2nd Cavalry Dirision (Suwalki) at present in Wilna; 26th Infantry Division and 26th Artillery Brigade (Grodno); 27th Infantrs Division and 27th drtillerg Brigade (Wilna). 2Sth Infantry Division (Dünaburg) belougs now to the 3rd Army Corps (Riga). 28th Artillery Brigade (Witebsk) belongs now to the 3rd Arm5 Corps (Riga).

3rd Army Corps (Riga) : consisting of the 3rd Cavalry Dirision and 25th Infantry Division (Kovno), belongs now to the newlyformed 16th Army Corps. 29th Infantry Division aud 29th Artillery Brigade in Riga. 25th Artillers Brigade in Wilkomir, belongs now to the newly-formed 16th Army Corps. 
4tls Army Corps (Minsk) : consisting of the th Cavalyy Division in Bijalistnck, 5th Rile Brigade (Wilna), transferred to Suwalki. 30th, 41st (belongs now to the 16th Army Corps), and 47th Rescrre Infantry Divisions, 30th and 4lst (now in 16th $\Lambda_{1 m y}$ Corps) Artillery Brigade (Minsk). 16th Infantry Division (Mogileff), transferred to Bijalistock and Wolkorski. 45th Reserre Infantry Division (Dünabnrg). 46th Reserre Infantry Division (Wilna). 16th Artillery Brigade (Gomely), transferred to Bijalistock and Wolkorski. 2nd Fngineers and Railway Brigade (Riga), transferred to Vilna.

16th Army Corps (Witcbsk): consisting of 25th Infantry Division and 25th Artillery Brigade (Dünaburgr). 4lst Infantry Division (Mogileff). 4lst Artillery Brigade (Gomel).

This is a norly-formed Arms Corps.

Strength of the whole military district, Wilna, in 1891 :-

\section{0 squadrons, 156 battalions, 56 batteries.}

\section{IVth MCilitary Dis!rict, Warsay.}

Commander : General (of caralry) ron Gourko.

3rd Guard, Caralry Brigade, iVarsaw.

3rd Guard, Infantry Division, Warsaw.

3rd Guard, Artillery Brigade, Warsaw.

5th Army Corps (IVarsaw) : consisting of tho 5th Carally Division (in Wloclarsk), 7th Infantry Dirision, 7th Artillery Irigade (Radom), 10th Infantry Division (Warsar), 10th Artillery Brigade (Lodicz).

6th Army Corps (Warsar): consists of the Kuban Cossack Division of Warsaw. Gth Cavalry Division, th Infantry Division (Lomzn). 6th Infantry Division (Plock). 8th Infantry Dirision, Warsaw (belongs sinco 1889 to the 15th Army Corps). 4th Artillery Brigade (Ostrog), 6th Artillely Dirision (Pultusk), trinsferred to Warsaw in 18S9. 8th Artillery Brigade (Lodz), transferred to the 15th Arms Corps in 1889.

14th Army Corps (Lublin): consisting of the 14th Caralry Division (Censtoclau), transferred to Kiclzo in 1889. Don Cossack Caralry Division ('Zamosk), belongs to 15th Army Corps since 1859. 1st Rifle Brigade at Wloclarsk. 2nd lRifle Brigade (Censtochan). 17th Infantry Division (Sicdlec), transferred to Lublin and Wlodorn in 1889. 18th Infantry Division (Iublin). 17th Artillory Brigado (Bjela), transforred to Lublin and Wlodova. 18th Artillery Brigade (Iublin). 4th Engineer Brigade (Warsaw). 16 reserre infantry cadre battalions, which in case of war would form

The 4Sth Infantry Division at Warsaw,

$\begin{array}{llll}\text { 40th } & " & " & \text { Noro-Georgicrsk, } \\ 50 \mathrm{tl}_{1} & " & " & \text { Lublin, and } \\ \text { 5lst } & " & " & \text { Brest-Litorski. }\end{array}$


15th Army Corps, Warsaw: lately formed from parts of the old 15th Corps (Kazan district) and the 6th Corps, consisting of -

The Don Cossack Dirision, Samostje.

löth Army Cavalry Division, Lublin.

2nd Infantry Troop Division, Brest-Litorski.

2nd Artillery Brigade, Bjela.

Sth Infantry Troop Dirision, Warsaw.

Sth Artillery Brigade, Lowitsch.

Grand total of the IVth Warsaw Military District; including the changes above noted, which constitute a reinforcement, since 1888 , of 30 battalions, 278 squadrons, and 5 batteries :-

\section{6 battalions.}

6 technical battalions.

134 squadrons.

60 batteries.

Ith Irilitary District, Kieff.

Commander : General-Adjatant and General (of infantry) Radetzki.

9th Army Corps, Kieff. 'This corps has been lately formed from parts of the 9th Corps (Orel) and the 12th Corps, and mored to Kicft; it now consists of-

The 9th Army Cavalry Tivision, Romni.

5 th Arinj Infantry Division, Tschernigoff.

5th Artny Artillery Brigade, Nieschin.

33rd Army Infantry Dirision, Kieff.

33rcl Army Artillery Brigade, Kieff.

3rd Fingineer Brigade, Kieff.

4 reserve battalions (forming 55th Reserre

Division), Kursk.

10tb Army Corps, Kharkoff. This corps has been lately formed from the old 10th Corps, and transferred to the Kieff Military District; it consists of-

The 10th Army Cavalry Dirision, Klarboff. 9th Army Iufantry Dirision, Poltawa. 9th Ar'mJ Artillery Brigade, Poltawa.

3lst Infautry Division, Kbarkoff.

31st Artillery Irigade, Bielgorod.

4 reserre battalions to form 54 th Reserve Division.

11th Army Corps, Zitomir, consisting of -

The 11th Cavalry Division, Dobno.

11 th Infantrs Division, Luck.

32nd Infantry Division, Zitomit.

11th Artillery Brignde, Rorno.

32nd Artillery Brigade, Berditscheff. 
12th Army Corps, Kieff, consists of-

'The 12th Caralry Division, Staff in Kieff, now in Winuiza; the 4 regiments of this Caralry Dirision were mored so far back as 1888 to the Austrian frontier, between Troskuroff and Kamenicc-P'odolsk.

The 3rd Rifle Brigade, Tulcin.

12th Infantry Division, Micziburie.

19th Infantry Dirision, Uman.

8 reserre infantry cadre battalions, to form in war-time, the 52nd Infantry Dirision at Kieff, and the 53rd Infantry Division at Winniza.

The 12th Artillers Brigade, Winniza.

19th Artillery Brigade, Smiela.

3rd Fngineer Brigade, Kieff.

Thus, the grand total of the Kicff Military District, which in 1883 was 76 battalions, $4 S$ squadrons, and 4 horse and 24 field batteries, is now, 1891-92,

$$
\begin{aligned}
& 156 \text { battalions, } \\
& 70 \text { squadrons, } \\
& 63 \text { batteries; }
\end{aligned}
$$

or has been nearly doubled.

\section{TIth Military District, Odessa.}

7th Army Corps, Serastopol, consists of-

The 7th Caralry Dirision, Elizabcthgrad. 13th Infantry Dirision, Sinferopol. 34th Infantrs Division, Ekaterinoslar. 13th Artillery Brigade, Sevastopol. 3tth Artillery Brigade, Klierson.

Sth Army Corps, Odessa, formed of-

The 8th Cnralry Division, Kiscleneff.

4th Riflo Brigade, Taganrog.

14th Infantry Dirision, Kischeneff.

15th " " Odessa.

Twelvo infantry reserve cadre battalions, forming, in case of war four reserve divisions':-

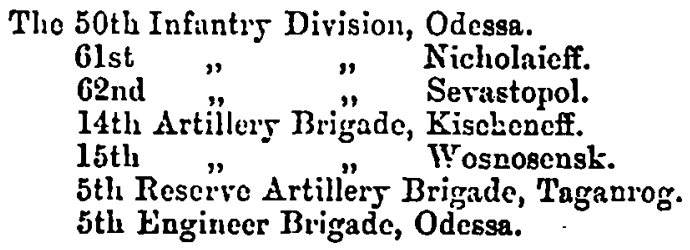


Grand total Military District, Odessn-

$$
\begin{aligned}
& 86 \text { battalions. } \\
& 48 \text { squadrons. } \\
& 4 \text { H.A. batterics. } \\
& 30 \text { ficld batteries. }
\end{aligned}
$$

\section{IrITh Mrilitary District, Kharkoff.}

Broken up in 18S9, and partially incorporated in the Vth, or Kieff, Military District.

9th Army Corps, Orel, consisted of-

$$
\begin{aligned}
& \text { 'Whe 9th Cavaliy Division, Romai. } \\
& \text { 5th Infantry Division, Cernizofi. } \\
& \text { 36th " Orel. } \\
& \text { 5th Artillers Brigade, Nieschin. } \\
& \text { 36tl " " Mcensk. }
\end{aligned}
$$

10th Army Corps, Kharkoff, consisted of -

$$
\text { The 10th Caralry Division, Kugnieff. }
$$

9th Infantry Division, Poltawa.

9th Artillery Brignde, Poltawa.

Kharkoff.

31st " "Bielgorod.

4th Reserre Artillery Brigade, Kursk.

Twelre infantry and rescrve cadre battalions, forming, in case of war, the 57th, $58 \mathrm{th}$, 59th Infautry Divisious, Charkoff, Kursk, Orel, respectirels.

Grand total since the tinnsfers and reduction of 1888 :--

76 battalions.

48 squadrons.

4 II.A. batteries.

30 ficld batteries.

N.B.-Thus it will be seen that the incrense in the Vth Military District, Kieff, has been chiefly carried out at the expense of the VIIth

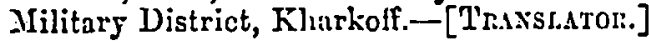

\section{VIIIth Military District, LYoscow.}

Commander H.I.H. Grand Dute Sergius, dec.

Grenadier Corps at Moscow, consists of -

I'he lst Grenadier Division, Moscow.

$\begin{array}{lll}\text { 2nd } & \text { " } & \text { Kaluga, now in Mloscow. } \\ \text { 3rd } & \text { " } & \text { Tambor, now in Moscow. }\end{array}$




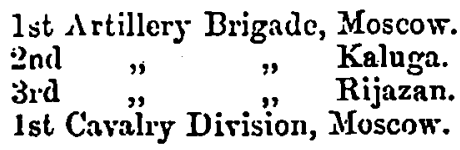

13th Arwy Corps, MLoscow, consisting of-

'The 13th Cavalry Division, Rijazan, now in Lnblin with 15th Corps. 1st. Infantry Division, Moscow.

3rd " $" \quad$ N. Norgorod, sent to 17th Corps.

35th " " Jaroslar, sent to 17th Corps.

1st drtillery Brigade, Moscow, now at Wiasma.

3rd " " Paulorski, sent to 17th Corps.

35th " \#ostor, sent to 17th Corps.

3rd Reserve Artillery Brigade, Smolensk.

2nd

"

Serpuchoff.

Twenty infantry rescrve cadro battalions, forming, in casc of war, the following reservo divisions, viz. :-

56th Division, MLoscow; 57th Division, Vladimir; and the 58th Division, Orel.

17th Army Corps, Nishni-Norgorod, newly formed, commanded by Licutenant-General Saljesoff, consists of-

The Brd Infantry Division, N. Norgorod.

35th "Jaroslav.

3rd Artillerg Brigade, Paulorsk.

35th" " Rostuff.

Four reserse cadre battalions, forming, in war time, the j9th Reserve Division, Jaroslar.

N.B.-This army corps is nearly entirely formed of transfers from the 13th Mloscow Army Corps.

Grand total VIIIth Military District, MLoscow, in 1891 :-

132 battalions.

24 squadrons.

56 batteries.

IXth Mrilitary Dislrict, Kazam.

Commander, Gencral-sdjutant, and General (of infantry) Jeschtschèrinoff.

15th Army Corps, Kazan, formed in 1888, but now mostly transferred to the IVth Military District, Warsaw, consists of-

The Astrakhan Cossack Cavalry Regiment, Knzan, now in Astrakhan.

Sixteen sotnias Orenburg Cossacks with two horse artillery

Cossack batteries, Orcuburg. 
63rd Infantry Division, Kazan. Gith " " Penza.

65th " " " Ssamara, besides the six local battalions at Kazan and Orcnburg.

Grand total IXth Military District, Kazan :-

50 battalions.

20 Cossack sotnias.

2 horse artillers batteries.

1으 field " "

Xth Military District, Province of the Don.

Ataman, Iieutenant-General Prince Swiatopolsk-Mirski.

The 12th Don Cossack Cavalry Regiment at and about NovoCerkask, which is at present the seat of the Don Cossack administration.

IIth Military District, Caucasus.

Commander: General-Adjutant and General (of caralry) Dondokòff. Korsakoff.

Ist Caucasiun Arms Corps, Tiflis, consists of-

The ist Cancasus Cossack Caralry Division, Tillis.

2nd " " " Jisabethpol.

Caucasus" Grenndier Dirisions, Tiflis.

38 th Infantry Division, $\Lambda$ chalzich, now in Kutais.

39 th

Alexandropol.

Caucasus"Grenadier Artillery Brigade, Tillis.

38th Artillery Brigade, Achalzich.

39th " " Kars.

2nd Caucasian Army Corps, Tiflis, consists of-

'l'he 3rd Caucasian Cavalry Division, Helenendorf, now in Tiflis.

Kuban Cossack Cavalry Brigade, Ekaterinodat.

T'erek " " Vladikavkas.

Caucasus R̈ifle Brigade, 'Iiflïs.

19th Iufantry Division, Stàvropol, transferred to 12 th Corps, Uman.

20ih " " Vladikarkas.

21st " " Petrorsk, now in Temir-Khan.

19th Artillery Brigade, Stivropol, transferred to the 12th

2)th $\quad$ a $\quad$ Vladikarkas.

21st " . " Temir-han-Schura. 
2nd Infantry Dirision, Kazan. 40th " " Ssaratoff.

Twelve "infantry" reserve cadre battalions to form, in case of war, the-

Kaban Artillery Brigade, Ekaterinodat.

Cancasus Encinecr Brigade, 'J'iflis.

2 Cossack rifte hattalions and 18 reserre battalions.

Grand total of the XIth Militars District, Caucasus :-

Grand total, 1888 :-

$$
\begin{aligned}
& 120 \text { battalions, } \\
& 102 \text { squadrous, } \\
& \left.\begin{array}{l}
6 \text { Hi.A. } \\
40 \text { ficld }
\end{array}\right\} \text { batteries, }
\end{aligned}
$$

and in 1891, after the reinforcement of the Vth Military I)istrict, Kieff, from the Caurasus :

$$
\begin{aligned}
& 100 \text { battalions, } \\
& 90 \text { squndrons, } \\
& 42 \text { batteries. }
\end{aligned}
$$

Fortress Artillery for the uhole Empire.

This force especially told off for the attack and defenee o fortresses is thus distributed divided into battalions :

$$
\begin{aligned}
& 6 \text { battalions in Kronstadt. } \\
& 6 \text {. "Modlin. } \\
& 2 \text {, ", "Svenborg. } \\
& 2 \text { " "Wy-borg. } \\
& 1 \text { " Dünamünde. } \\
& \text { * " " "Dünaburg (siege train). } \\
& 4 \text { : " Brest-Litorski (siege train). } \\
& 4 \text {, "Ivangorod (siege train). } \\
& 3 \text {.. " Kieff. } \\
& 2 \text { " "Ostclakioff. } \\
& 1 \text {." "Bobruisk. } \\
& \text {; ., "Warsaw. } \\
& 1 \text { " " Bender. } \\
& 3 \text { ". " Kertsch. } \\
& 1 \text { " "Kars. } \\
& 1 \text { " "Batoum. } \\
& 1 \text { ". "Alexandropol. } \\
& \text { l " "Darohestan. } \\
& 1 \text {,. "Poti. } \\
& 1 \text {., "Michaclorsk. }
\end{aligned}
$$

Total 48 battalions. 


\section{IIIth Military District, I'urkestan.}

Its cstablishment consists of-

46 Cossack Carally Sotnias : of these, howerer, 18 squadrons were sent to Europe in 1889, so there remain-

28 Sotnias Cossack Caralry.

3 Brigades of Ritles, at $\Lambda$ skabad and Merr.

20 Linc Battalions, for Tashkend, Samarkand, and Kerki.

3 Local Battalions.

Engiucer Battalion.

\& Railway Battalions, Tashkend, now at Kezil-Arrat and Samirksind.

2 Hor'se Artillery

1 Mountain Batteries.

$\{$ Turkestan drtillery Brigade.

Ginnd total :

32 battilions (the establishment being $34 \frac{1}{2}$ ).

25 (of an cstablislment of 46 ) sotnias. 3 ir.h. batteries.

10 field batteries.

N.B. From this district 18 squadrons and $2 \frac{1}{2}$ battalions have been directed westwards.-['T'isiss.itor..]

\section{Siberita. \\ XIIIh Military District, West Sileria.}

16 Cossack Sotnins of Cavalry in Dscliarkend and Wierni.

8 line Battalions.

3 Local Battalions.

1 Company Luginecrs.

1 Monntain Mounted Battery.

1 West Siberian Artillery Brigade.

Total :

$$
\begin{aligned}
& 11 \text { battalions. } \\
& 16 \text { sotnias of cavalry. }
\end{aligned}
$$

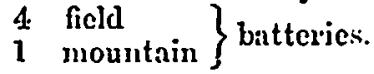

XIVth and XVth. Jilitary Districts, Irliutsli and Amur.

9 Cossnck sotnias of cavalry.

2 Brigades of Ritles (transferrel to Europe in 188?).

2 Cossack infautrs battalions.

6 infantry battalions.

2 sotnias $\Lambda$ mur infantry. 
6 infantry rcserro cadre battalions.

1 Fast Siberian Artillery Brigade of 4 batteries.

2 Cossack H.A. batteries.

1 Company Engineers.

Total 12 battalions (the Rifles deducted).

0 sotnias, caralry.

6 battcrics.

Summary.-The whole length of the German and Austrian frontiers, from Ijiban to Kamenicc-Podolsk, is watched bs a coutinnous chain of llussian Cavalyy Corps, belonging to the centresWarsaw, Wilna, Kieff, which shelter Hoscow and Odessa. Thus the enormous force of seventecn Russian Army Corps is grouped in a space more than twice as large as our whole Fatherland (AustriaHungars).

There are now in the Military District of Tilna four Army Corps, as against three in the spring of 188S. In the Wrarsaw District, at portion of the Guard Corps, and behind this, four more Army Corps; so that the available force in this district is stronger lis:

24 battalions,

27 squadrons, and

4 b.atteries,

thun it was in $188 \mathrm{~s}$.

The reinforcement of the Vth Military District, Kieff, is most striking: until 1888 there were only 2 corps in it; now the VIIth Mlilitary District, Kharkoff, is incorporated with it, and 20 battalions aud 12 squadrons lare been transferred to it from the Cancasus; so that now the.Kieff District comprises 4 Army Corps, which constitutes a reinforcement here alone of :

\section{0 battalions, \\ 22 squadrons, and \\ 3 batterics.}

'l'be Military District of MLscow recives a now corps, and now numbers 24 battalions and 4 batteries more than in 1ESS; whilst 24 squadrons have been sent from it westwards.

From these staternents it can be understood that the tendency of the Irussian War Ministry since 1888 has been to bring suecessive bodies of troops from the enstern provinces, so as to strengthen very considerably the militar's districts which lie nenr the German and Austrian frontiers. 